\begin{tabular}{lccccc}
\multicolumn{8}{c}{ 東京慈恵会医科大学第二内科 } & \\
河野 & 英雄 & 細谷 & 龍男 & 児玉 & 和也 \\
松本 & 章 & 尾田 & 芳隆 & 小椋 & 陽介 \\
酒井 & 聡一 & 宮原 & 正 & &
\end{tabular}

\title{
TWO CASES OF XANTHINURIA IN BROTHERS
}

Hideo Kono, MD, Tatsuo Hosoya, MD, Kazuya Kodoma, MD

Akira Matsumoto, MD, Yoshitaka Oda, MD, Yosuke Ogura, MD

Soichi SAKAI, MD and Tadashi MIYAhara, MD

The Department of Medicine, The Jikei University School of Medicine, Tokyo 105

\begin{abstract}
概要 慢性腎不全の加療を目的に入院した症例に先天性単腎症と著明な低尿酸血症が認められ た。低尿酸血症の家族内発症の有無を調査した結果，この症例の末弟にも同様の低尿酸血症が

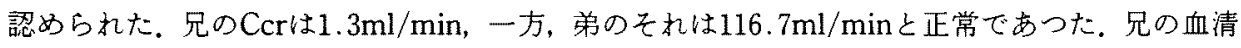
尿酸值は $0.1 \mathrm{mg} \%$ ，尿酸クリアランスは $0.06 \mathrm{ml} / \mathrm{min}, 1$ 日尿中尿酸排泄量は $6.0 \mathrm{mg} / 24 \mathrm{~h}$, 一方, 弟はそれぞれ $0.2 \mathrm{mg} \%, 0.59 \mathrm{ml} / \mathrm{min}$ ，拉よび $1.7 \mathrm{mg} / 24 \mathrm{~h}$ といずれる著明な低值を示していた。 な扰，弟にpyrazinamide suppression testを行なつたが，尿酸再吸収率，尿酸分泌率は正常で あつた，尿酸の前駆物質であるhypoxanthine，xanthineを測定した結果，血浆hypoxanthine濃 度は兄で $0.22 \mu \mathrm{g} / \mathrm{ml}$, 弟で $0.28 \mu \mathrm{g} / \mathrm{ml}$, 血浆xanthine濃度は兄で $5.85 \mu \mathrm{g} / \mathrm{ml}$, 弟で $0.75 \mu \mathrm{g} / \mathrm{ml}$,

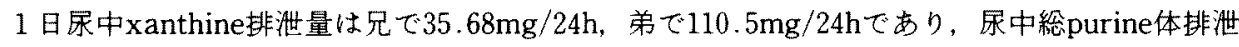
量に対するxanthineの尿中排泄率は兄で $67.1 \%$ ，弟で59.6\%と尿中xanthineの排泄率が非常に 高く，腎機能正常の弟では尿中hypoxanthine排泄量も著増していた。さらにこの兄弟の十二指 腸粘膜を生検し，その組織中のxanthine oxidase活性を測定した結果, 活性は全く認められな かつた，以上よりこの兄弟をxanthine oxidase欠損によるxanthine尿症と診断した。
\end{abstract}

\section{1.はじめに}

Xanthine尿症はxanthine oxidase酵素欠損の 結果血中尿酸の産生が低下し，尿酸の前駆物質で あるxanthineが尿中に多量に排泄されるきわめ てまれな疾患”で，同一家系内に発症することが 知られて扣り，一般に常染色体劣性遺伝と考えら れている213).

最近著者らは，先天性単腎症に著明な低尿酸血 症を合併し，慢性腎不全を発症した症例を経験し

[昭和 58 年 3 月 17 日受稿]

本研究の 1 部は三浦医学研究振興財団によつた。

本研究の 1 部は第11回日本腎䁍学会東部々会（昭和 56 年 5 月21日), 第10回尿酸研究会 (昭和56年 8 月29日) において 報告した。
た。この症例に尿酸代謝に関する詳細な検討を加 えた結果，低尿酸血症の原因はxanthine oxidase 欠損によるxanthine疗症であることが判明した。

そこでこの患者の三代にわたる家系，合計14名 について尿酸代謝に関する調查を行なつた結果， 発端症例の末弟にもxanthine疗症が見出された。 以下，きわめてまれなxanthine尿症の兄弟例の 詳細について報告する。

\section{2. 発端症例}

\section{症例：37才, 男性, 会社員.}

主訴: 呼吸困難, 乏尿.

既往歴：3才時，原因不明の高熱疾患に罹患 し左眼を失明したが，その詳細は不明である。15 才時，巨大な膀脂結石のため某大学病院で膀胱切 
表 1. 入院時検査成績（発端症例）

\begin{tabular}{|c|c|c|c|c|c|c|c|}
\hline \multicolumn{2}{|l|}{ Urinalysis } & \multicolumn{3}{|l|}{ Chemistry } & \multicolumn{3}{|l|}{ Serology } \\
\hline Protein & (世) & T.P. & \multicolumn{2}{|c|}{$6.6 \mathrm{~g} \%$} & CRP & $(-)$ & \\
\hline Sugar & $(-)$ & alb. & \multicolumn{2}{|c|}{$4.17 \mathrm{~g} \%$} & RA & $(-)$ & \\
\hline \multirow[t]{4}{*}{ Sediment } & RBC $3 \sim 5 / \mathrm{HPF}$ & $\alpha_{1}$-glob. & \multicolumn{2}{|c|}{$0.32 \mathrm{~g} \%$} & \multicolumn{3}{|c|}{ Blood gas analysis } \\
\hline & WBC $2 \sim 3 / \mathrm{HPF}$ & $\alpha_{2-\text { glob. }}$ & \multicolumn{2}{|c|}{$0.94 \mathrm{~g} \%$} & $\mathrm{pH}$ & \multicolumn{2}{|c|}{7.19} \\
\hline & Hyal. cast (\#) & $\beta$-glob. & \multicolumn{2}{|c|}{$0.53 \mathrm{~g} \%$} & $\mathrm{PO}_{2}$ & 92 & $\mathrm{mmHg}_{\mathrm{g}}$ \\
\hline & Gran. cast (H) & $\gamma$-glob. & \multicolumn{2}{|c|}{$0.63 \mathrm{~g} \%$} & $\mathrm{PCO}_{2}$ & 35 & $\mathrm{mmHg}_{\mathrm{g}}$ \\
\hline \multicolumn{2}{|l|}{ Feces } & Al-P & 8.5 & KA & $\mathrm{HCO}_{3}^{-}$ & 13 & $\mathrm{mmol} / \mathrm{L}$ \\
\hline \multicolumn{2}{|l|}{ Stool occult } & GOT & 8 & u & $\mathrm{BE}$ & -14 & $\mathrm{mmol} / \mathrm{L}$ \\
\hline \multicolumn{2}{|c|}{ Parasite eggs (-) } & GPT & 5 & $u$ & \multicolumn{3}{|l|}{ Renal function } \\
\hline \multicolumn{2}{|c|}{ Blood } & LDH & 136 & $u$ & BUN & 137.8 & $\mathrm{mg} \%$ \\
\hline ESR & $29 \mathrm{~mm} / \mathrm{hr}$ & T. chol. & 190 & $\mathrm{mg} \%$ & Creatinine & 18.8 & $\mathrm{mg} \%$ \\
\hline RBC & $219 \times 10^{4} / \mathrm{cmm}$ & $\mathrm{Na}$ & 141 & $\mathrm{mEq} / \mathrm{L}$ & U.A. & 0.1 & $\mathrm{mg} \%$ \\
\hline wBC & $4.5 \times 10^{3} / \mathrm{cmm}$ & k & 5.1 & $\mathrm{mEq} / \mathrm{L}$ & urine vol. & $300-500$ & $\mathrm{ml} / 24 \mathrm{hrs}$ \\
\hline $\mathrm{Hb}$ & $6.6 \mathrm{~g} \%$ & $\mathrm{Cl}$ & 109 & $\mathrm{mEq} / \mathrm{L}$ & Cer & 1.3 & $\mathrm{ml} / \mathrm{min}$ \\
\hline Hec & $19.0 \%$ & $\mathrm{Ca}$ & 7.6 & $\mathrm{mg} \%$ & Cua & 0.06 & $66 \mathrm{ml} / \mathrm{min}$ \\
\hline Platelet & $12.3 \times 10 \% / \mathrm{cmm}$ & $\mathrm{PO}_{4}$ & 6.5 & $\mathrm{mg} \%$ & uVua & 6.0 & $\mathrm{mg} / 24 \mathrm{hrs}$ \\
\hline
\end{tabular}

石術を受けたが，結石成分は明らかでない

現病歴：1973年 8 月近医にて貧血を指摘され た。その後全身倦总感, 食欲不振が出現し，下肢 に浮腫が認められるようになつたが放置してい た. 1980年 4 月 12 日, 呼吸困難が出現したので当 科外来を受診し，緊急入院した。

入院時現症：血圧198/118mmHg, 脈拍112/ 分整. 顔面蒼白で苦悶状, 意識は傾眠状態であつ た。眼球結膜に黄染はないが，眼䀫結膜に貧血を 認めた。胸部では両下肺野に湿性ラ音, 心尖部に 収縮期雑音とfriction rubを聴取した。

検查成績： 主な検査成績は表 1 に示すごとく で，BUN，血清 creatinine の著明な上昇， creatinine clearance (Ccr) の著明な低下. 代謝 性acidosis, 高カリウム血症などが認められたが,

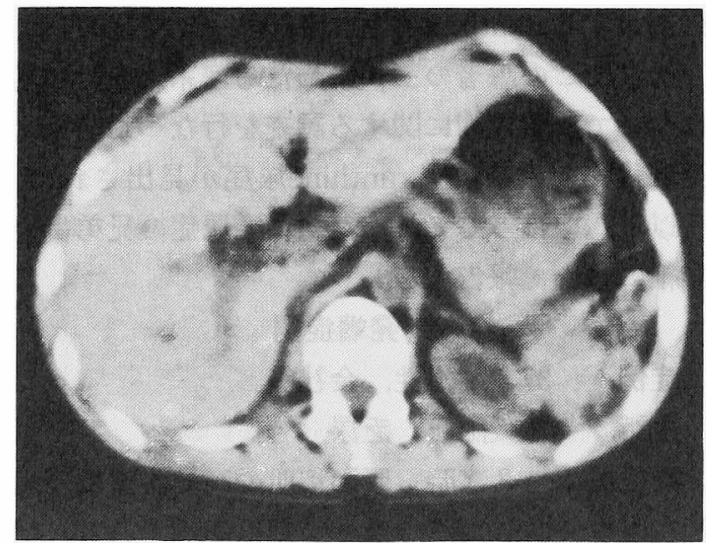

困 1. 発端症例の腹部CT
血清尿酸および尿中尿酸は著しい低值を示してい た.

なお腹部CTにより左腎の萎縮および右腎の欠 損が認められ，膀胱鏡にて右尿管口の欠損を確認 した（図 1 ）.

入院後経過： 末期慢性腎不全による尿毒症と らつ血性心不全の診断で，ただちにTenckhoff catheterを插入し，腹膜透析を開始した，その後， 呼吸困難，心不全などの症状はしだいに軽快した ため，入院第88病日に左腎の開放性腎生検を施行 した。その組織像はほとんどの糸球体が硝子化に 陥つており，さらに間質の線維化，細胞浸潤，尿 細管の萎縮拡張を認め, 慢性腎孟腎炎様病变の末 期像と考光られた（図 2 ）.

その後本症例の血液浄化法には $\mathrm{CAPD}^{4)}$

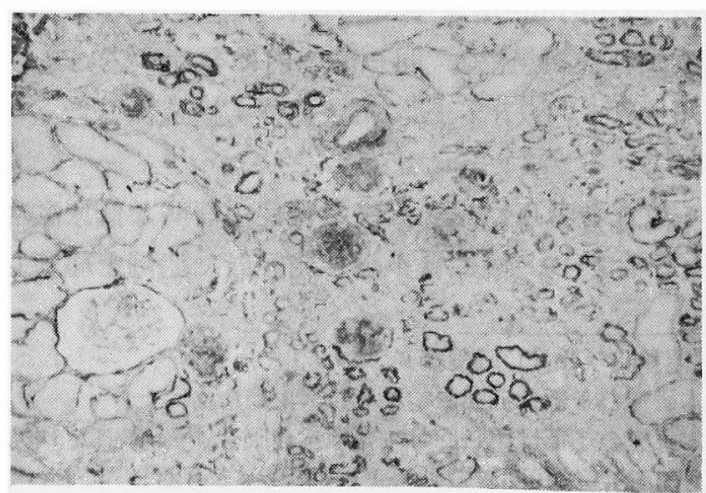

図 2，発端症例の堅生検像（Pam Masson × 100) 
(continuos ambulatory peritoneal dialysis) を行 ない, 1980年11月 6 日退院した。

\section{3. 家系調査}

本症例の 3 代にわたる家系14名を対象として， 血清括よび尿中尿酸, allantoin，血浆技よび尿中 hypoxanthine, xanthineを測定した。

なお検体は早朝空腹時採血のものを使用し，尿 酸はuricase-catalase法による autoanalyzerで測 定し, hypoxanthine, xanthineはheparin加採血の ものを検体とし，山北ら 5)の方法に従いprecolumn を併用した高速液体chromatographyを用いて測 定した。交たallantoinはVogelsらのの方法に従い 測定した。

本症例の父は70才 10 人兄弟の第 1 子で，同胞 9 名中 5 名存命である。それぞれの血清尿酸，allantoin扣よび血浆hypoxanthine, xanthineを測 定したところ，いずれも controlである健常者と差 を認めなかつた，本症例の母は69才で7人兄弟の 第 1 子であり，血清尿酸は $2.6 \mathrm{mg} \%$ とやや低值を 示したが，血浆hypoxanthine, xanthineおよび血 清allantoinは全て健常者と差を認めず，同胞 5 名 中 2 名存命であるが，この 2 名に対しても同様の 検討を加光た結果，いずれの検查値も健常者と差 を認めなかつた。

本症例の同胞は男性 5 名，女性 2 名で，男性 1 名は乳児期死亡，女性 1 名は子宮癌にて死亡して
いる.第 1 子は 48 才男性で血清尿酸は $5.5 \mathrm{mg} \%$, 第 4 子は 40 才女性で血清尿酸は $3.3 \mathrm{mg} \%$ ，第 6 子は 本症例, 第 7 子は 35 才男性で血清尿酸 $0.2 \mathrm{mg} \%, 1$ 日尿中尿酸排泄量は $1.7 \mathrm{mg} / 24 \mathrm{~h}$ と低尿酸血症打よ び低尿酸尿症を示した，本症例および末弟を除く 他の同胞 4 名の血浆hypoxanthine, xanthine扩よ び血清allantoinは健常者と差を認めなかつた。さ らに本症例の 5 才の息子の血清尿酸は $4.2 \mathrm{mg} \%$ と 正常であつた（図 3 ）。

\section{4. 低尿酸血症を呈した兄弟の尿酸代謝に関 する検査}

腎不全患者の兄を発端者として，その末弟にも 低尿酸血症が認められたため，この2名を対象と して，前述の検查項目に加兄てCcr，尿酸clearance (Cua)，疗中総purine体排泄量，十二指腸粘膜 に括けるxanthine oxidase活性を測定し，腎機能 正常な弟（Ccr $116.7 \mathrm{ml} / \mathrm{min}$ ) にはpyrazinamide suppression test (P.Z test) を施行した.

なお，xanthine oxidase活性は十二指腸粘膜を

表 2、腎機能々尿酸転送能

\begin{tabular}{c|c|c|c|c|c|c|c|c|c}
\hline & $\begin{array}{l}\text { S.U.A } \\
\mathrm{mg} \%\end{array}$ & $\begin{array}{l}\text { S.Cr. } \\
\mathrm{mg} \%\end{array}$ & $\begin{array}{l}\text { Crr } \\
\mathrm{m} / \mathrm{min}\end{array}$ & $\begin{array}{l}\text { Cua } \\
\mathrm{m} / \mathrm{min}\end{array}$ & $\begin{array}{l}\text { Cua } \\
/ \mathrm{Ccr}\end{array}$ & $\begin{array}{l}\text { UVua } \\
\mathrm{mg} / 24 \mathrm{hrs}\end{array}$ & $\begin{array}{l}\text { Fua } \\
\mathrm{mg} / \mathrm{min}\end{array}$ & \%TRua & \%TSua \\
\hline Original pt & 0.1 & 18.8 & 1.3 & 0.06 & 0.046 & 6.0 & 0.089 & - & - \\
\hline His brother & 0.2 & 0.9 & 116.7 & 0.59 & 0.005 & 1.7 & 0.467 & 97.7 & 92.3
\end{tabular}

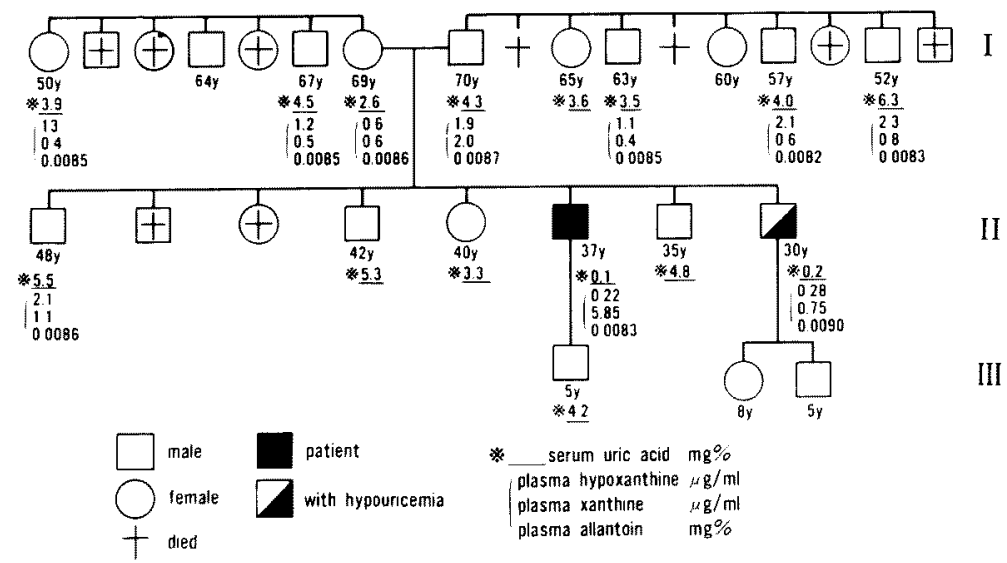

図 3，発端应例の家系 3 代に括ける血清尿酸，allantoin 括上び血浆hypoxanthine， xanthineの㭘查値 
表 3．血清および尿中allantoin

\begin{tabular}{|c|c|c|c|}
\hline & $\begin{array}{r}\text { Serum tevels } \\
\mathrm{mg} \% \\
\end{array}$ & $\begin{array}{r}\text { Urinary levess } \\
\text { mg/mit }\end{array}$ & $\begin{array}{c}\text { UV allanton } \\
\text { mg/24hss }\end{array}$ \\
\hline Original ot & 0.0083 & 0.0673 & 26.92 \\
\hline His brother & 0.00896 & 0.0639 & 108.63 \\
\hline $\begin{array}{l}\text { Healthy controls } \\
14 \text { cases }\end{array}$ & $\begin{array}{l}0.0082 \\
\sim 0.0090\end{array}$ & $\begin{array}{l}0.064 \\
\sim 0.067\end{array}$ & 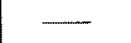 \\
\hline
\end{tabular}

内視鏡下に採取し，酵素反応により生成する尿酸 を, Gilford 2400 型分光光度計を用いて $37^{\circ} \mathrm{C} ， \lambda$ $293 \mathrm{~nm}$ での吸光度の上昇をもつて測定した7).

表 2 は兄弟例の尿酸転送能と腎機能を示したも ので, Cua, Cua/Ccrならびに尿酸沪過量はいずれ も著しい低值であつた。

一方，P·Z testを施行した結果は表 2 に示すごと くで，尿酸再吸収率（\% TRua），尿酸分泌率（\% TSua）いずれも正常であつた。

表 3 は兄弟例の血清および尿中allantoinを健 常者14名のそれと比較検討したものである，両症 例の血清扰よび尿中allantoinは健常者と差を認 めなかつた。

次に尿酸生成過程の検討を目的として尿酸の前 駆物質であるhypoxanthine, xanthineの血中およ び尿中動態を検討した。

表 4 に示すごとく血浆hypoxanthine濃度は兄 $0.22 \mu \mathrm{g} / \mathrm{ml}$, 弟 $0.28 \mu \mathrm{g} / \mathrm{ml}$, 血浆xanthine濃度は兄 $5.85 \mu \mathrm{g} / \mathrm{ml}$, 弟 $0.75 \mu \mathrm{g} / \mathrm{ml}$, 1 日尿中hypoxanthine排泄量は兄 $11.48 \mathrm{mg} / 24 \mathrm{~h}$, 弟 $73.1 \mathrm{mg} / 24 \mathrm{~h}$, さら に1日尿中xanthine排泄量は兄 $35.68 \mathrm{mg} / 24 \mathrm{~h}$, 弟

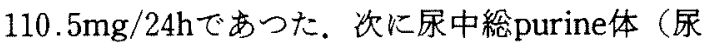
酸+hypoxanthine+xanthine）排泄量に対する xanthineの尿中排泄率を算出すると，兄は $67.1 \%$ ，弟59.6\%であつた。な招，著者らが測定 した健常者 9 例の血浆 hypoxanthine濃度は $0.27 \sim 2.5 \mu \mathrm{g} / \mathrm{ml}$, 血浆 xanthine濃度恃 $0.4 \sim 2.0$ $\mu \mathrm{g} / \mathrm{ml}, 1$ 日尿中 hypoxanthine 排泄量は 7.4 27. $1 \mathrm{mg} / 24 \mathrm{~h} 1$ 日尿中 xanthine 排泄量は $4.3 \sim 18.5 \mathrm{mg} / 24 \mathrm{~h}$ であり，尿中総purine体排泄量 に対するxanthineの尿中排泄率1４\%であつた。 すなわち，両症例の血浆hypoxanthine濃度括よび 弟の血将xanthine濃度は健常者と差を認めなか つた。しかし，兄の血浆xanthine濃度は健常者に
表 4.血等および尿中のhypoxanthine, xanthine

\begin{tabular}{|c|c|c|c|c|c|c|c|}
\hline & \multicolumn{2}{|c|}{ Plasms levels $\mu 8 / \pi$} & \multicolumn{2}{|c|}{ Uninary tevels ms\% } & \multicolumn{2}{|c|}{ UVonypurinol me/2thrs } & \multirow{2}{*}{ 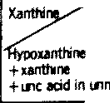 } \\
\hline & Hyooxanthine & Xarthine & Hypo:anthine & Kanthine & Hypoxanthise & Xanthure & \\
\hline Oraginal ot. & 0.22 & 5.85 & 2.87 & 8.92 & 11.40 & 35.68 & $67.1 \%$ \\
\hline His brother & 0.28 & 0.75 & 4.3 & 6.5 & 73.1 & 110.5 & $59.6 \%$ \\
\hline $\begin{array}{r}\text { Heathy controls } \\
9 \text { cases }\end{array}$ & $\begin{array}{l}0.27 \\
\sim 2.5\end{array}$ & $\begin{array}{l}0.4 \\
\sim 2.0\end{array}$ & $\begin{array}{r}2.87 \\
\sim 30.51\end{array}$ & $\begin{array}{c}3.86 \\
\sim 9.82\end{array} \mid$ & $\begin{array}{l}7.4 \\
\sim 27.1\end{array}$ & $\mid \begin{array}{l}4.3 \\
\sim 18.5\end{array}$ & $1 \sim 4 \%$ \\
\hline
\end{tabular}

比して高值を示した。また，1日尿中hypoxanthine排泄量は腎不全の兄では健常者と差を認 めないが，腎機能正常の弟では健常者の約 3 倍に む達していた。ささに 1 日氺中xanthine排泄量は 兄では健常者の約 2 倍, 弟では約 6 倍の值を呈し た。

さらに両症例の十二指腸粘膜における xanthine oxidase活性を測定した結果，その活性は全く 認められなかつた。な拉，同時に測定した健常者 十二指腸粘膜のxanthine oxidase活性は17nmol/ h/mg・proteinであつた．以上の成績から両症例を xanthine oxidase欠損によるxanthine尿症と診断 した.

\section{5. 考察}

先天性単腎症に著明な低尿酸血症を合併し，そ れに慢性腎不全を発症した症例を発端者とし，そ の弟にも低尿酸血症が認められ，精査の結果両症 例とすxanthine尿症であることが判明した。

Xanthine尿症はxanthine oxidase欠損により 尿酸の産生が低下し，その結果尿中尿酸排泄量が 著しく低下し，体内のpurineは尿酸の前駆物質で あるhypoxanthine, xanthineとして尿中に排泄さ

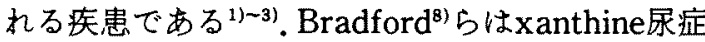
と健常者を比較して, xanthine疗症では血清尿酸 $0.8 \mathrm{mg} \%, 1$ 日尿中尿酸排泄量は平均 $6.5 \mathrm{mg} / 24 \mathrm{~h}$, 1 日尿中hypoxanthine排泄量は平均 $54.4 \mathrm{mg} / 24$ $\mathrm{h}, 1$ 日尿中xanthine排泄量は平均 $219 \mathrm{mg} / 24 \mathrm{~h}$ と 健常者と比較して尿中尿酸排泄量が極端に減少 し，尿中hypoxanthineおよびxanthineの排泄量が 非常に増加していることを報告している．著者ら が測定した健常人の1 日尿中hypoxanthine排泄 量は7.4 27.1mg/24h，1 日尿中xanthine排泄量 
は4.3 18.5mg/24hであり，本症例は 1 日尿中尿 酸排泄量 $6.0 \mathrm{mg} / 24 \mathrm{~h}$ ，弟は $1.7 \mathrm{mg} / 24 \mathrm{~h}$ と著しい低 下を認めており，1 日尿中hypoxanthine排泄量は 兄 $11.48 \mathrm{mg} / 24 \mathrm{~h}$, 弟 $73.1 \mathrm{mg} / 24 \mathrm{~h}$ と腎不全の兄は 健常者と差を認めなかつたが，腎機能正常の弟で は著増していた。また 1 日尿中xanthine排泄量は 兄 $35.68 \mathrm{mg} / 24 \mathrm{~h}$, 弟 $110.5 \mathrm{mg} / 24 \mathrm{~h}$ と健常者と比較 して兄弟ともにxanthine排泄量が増大しており， Bradfordらの報告しているxanthine疗症と同様 の成績であつた。

本症の合併症として hemochromatosis ${ }^{9}$, 筋 炎 ${ }^{10)}$, pheochromocytoma ${ }^{111}$, 乾癖 ${ }^{12)}$, talacemia

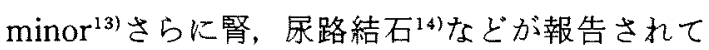
いる。しかし，発端症例にみられたようなxanthine尿症に腎不全が発症したとする報告はなく，本 症例はきわめて興味ある症例と考劣られた。本症 が腎不全に陥つた原因は明らかでないが，巨大膀 胱結石の既往がありここれにより尿流障害が生じ， さらに尿路感染がくり返されたことが容易に推察 される.さらに本症例が先天性単腎症であつたこ とが，腎不全に陥りやすくさせたるのと考光られ る。本症例の腎組織所見で, 系球体の変化に加光 て尿細管, 間質の変化が著明であることは, 上記 の推論を裏ずけている。な挔, xanthine尿症と単 腎症または幼児期の左眼失明との関連は明らかで はなかつた。

Xanthine疗症で疗路結石を合併する頻度は報 告者により異なるが, Cartier $5^{14)} は 38$ 例中15例 (39.5\%)に結石の合併を報告している。この結石 の成分としてxanthine結石のみが報告され， hypoxanthine結石の報告はない。この理由とし $て$, hypoxanthineはxanthineと異なり salvage機 構が働いて, inosine-5'-monophosphateに転換さ れる(15)ため，尿中のhypoxanthine排泄量がxanthine排泄量汪ど著増を示さないためと解釈されて いる. 事実, 本症例 $35.68 \mathrm{mg} / 24 \mathrm{~h}$, 弟は $110.5 \mathrm{mg} /$ $24 \mathrm{~h}$ と 1 日尿中xanthine排泄量は健常者に比較し て著明な増加を認め，1日尿中hypoxanthine排泄 量に比較して著しく多量であつた。

Xanthine尿症の確定診断にはxanthine
oxidase活性を測定することが必要である.Watts ら ${ }^{16}$ はmalignant melanomaで死亡した女性の剖 検時に, xanthine oxidase の組織別活性度を測定 し，最高值を示したのは空腸 $(12,100 \times 10 \mu \mathrm{M}$ xanthine oxidized $/ \mathrm{mg} \cdot \operatorname{protein} / \mathrm{h})$ で, 次いで肝 藏 $(5650 \times 10 \mu \mathrm{M}$ xanthine oxidized $/ \mathrm{mg} \cdot$ protein/ h)と報告している。著者らは内視鏡的に兄弟の十 二指腸粘膜を生検し, xanthine oxidase活性を代 科の方法》で測定したところ，兄弟とも十二指腸 粘膜にxanthine oxidase活性を全く認めなかつ た。

以上のことょりこの兄弟がxanthine oxidase欠 損によるxanthine尿症であると猃断し得た。

Xanthine疗症は著者らが調查し得た範囲では, 1954年にDentら ${ }^{11}$ にり報告されて以来，1976年 までに60例の報告があり，まれな代謝疾患の一つ である，本症の家族発生は1974年までの20年間に 24例の報告があり，その遗伝形式は常染色体劣性 遺伝が示唆されている。本邦では御巫らの調査 ${ }^{17}$ によると現在までに 8 例報告されているにすぎな い。

著者らもこの兄弟の家族 3 代14名に対して調査 したが，明らかな遺伝形式を解明するには至らな かつた。しかし少なくとも優性遺伝形式は示して

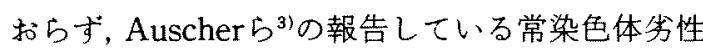
遺伝形式をとつている可能性は否定できない

\section{6. おわりに}

著者らは，先天性単腎症に著明な低尿酸血症を 合併し，それに慢性腎不全を発症した兄と腎機能 正常で，かつ著明な低尿酸血症を呈している弟を 経験した。家系 3 代の詳細な尿酸代謝について検 討の結果，本邦では現在までに 8 例しか報告され ていないxanthine oxidase欠損によるxanthine尿 症の兄弟例であることを確認した。

謝辞 本症例の解明にあたつて，東京女子医科大学りウ マチ痛風センター 西岡久寿樹先生, 虎の門病院検䍒科 化科辟先生括上び東京慈恵会医科大学青戸分院内科永 野尤先生の御協力を得たことを感謝します。

\section{文献}

1) Dent CE and Philpot GR: Xanthinuria, an inborn error (or deviation) of metabolism. 
Lancet $1: 182,1954$.

2) Wyngarden JB: Xanthinuria. In metabolic basis of inherited disease. Stanbury JB, et al, ed. Third Ed, Mcgraw Pub New York, 1972. p992.

3) Auscher $\mathrm{C}$, et al: Xanthinuria: Study of a large kindred with familial urolithiasis and gout. Biomed Express 27 : 57, 1977.

4) Oreopoulos DG, et al: A simple and safe technique for continuous ambulatory peritoneal dialysis (CAPD). Trans Amer Soc Artif Intern Organs $24: 484,1978$.

5) 山北博一, 他：アロプリノールに関する臨床薬理 学的研究 (第 2 報) 一続服用時の血浆中濃度の シミェレーションー。尿酸 $3: 178,1979$.

6) Vogls GD and van der Drift C: Differential analysis of glyoxylate diritives. Analytical Biochemistry $33: 143,1970$.

7) 化科甫啓：高尿酸血症（主として病態生化学的側 面).ファルマシフレビュー $4: 85,1980$.

8) Bradford MJ, et al: Study of purine metabolism in a xanthinuric female. J Clin Inv 47: 1325, 1968.

9) Ayvaxian JH: Xanthinuria and hemo- chromatosis. New Engl J Med 270: 18, 1964.

10) Chalmers RA, et al: Microscopic studies on crystals in skeletal muscle from two cases of xanthinuria. J Pathol 99: 45, 1969.

11) Engelman $\mathrm{K}$ Watts, et al: Clinical physiological and biochemical stujdies of a patient with xanthinuria and pheochromocytoma. Amer J Med 37: 839, 1964.

12) Holms EW Jr, et al: Xanthine oxidase deficiency: Study of a previously unreported case. Clin Chem 20:1076, 1974

13) Frayha RA, et al: Hereditary xanthinuria and xanthine urolithiasis: An additional 3 cases. J Urol 109: 871, 1973.

14) Cartier $P$ and Perignon JL: Xanthinurie. La Nouvelle Presse Medicale 22: 1381, 1978.

15) Seegmiller JE: Purine metabolism. Arth \& Rheum 18:681, 1975.

16) Watts RWE, et al: Xanthine oxidase activity in human tissues and inhibition by allopurinol. (4-hydroxypyrazole (3,4-d) pyrimidine. J Lab Clin Med 66:688, 1965.

17）御巫清允: 尿酸研究の現状と将来. 尿酸 $6: 1$, 1982. 